\title{
The impact of the characteristics of the audit committees on avoiding financial failure in Jordanian Industrial Public Shareholding Companies listed in ASE (Amman Stock Exchange) - Applied study
}

\author{
Dr. Ibrahim Y. A. Jwaifel \\ Assistant Professor \\ Jerash University
}

\begin{abstract}
:
The aim of this study was to identify the impact of the characteristics of the audit committees represented by (the size of the Audit Committee, the number of independent members and the number of meetings of the Audit Committee) on avoiding financial failure in Jordanian Industrial Public Shareholding Companies listed in ASE, which has been measured by adopting the Altman model to predict financial failure. The sample of the study consists of the industrial joint stock companies listed on the Amman Stock Exchange (ASE), which are up to (67) industrial companies until the end of 2017 , Distributed among (10) industrial sectors, according to the directory of companies from the official website of the ASE. The sample of the study included (49) companies which the conditions for selecting the sample apply to. The study was based on the analytical descriptive approach, which is based on using different statistical methods to analyze the data gathered from the field of the study sample to describe the variables of the study and answer its questions and test its hypotheses. The study obtained a number of results, the most important of which was that the percentage of industrial companies which are not threatened by financial failure according to Altman model reached (71.4\%), While the proportion of companies threatened with financial failure has reached (28.6\%), which indicates the ability of the majority of industrial companies to avoid financial failure, The most important recommendations of the study crystallize the need for regulatory bodies through the audit committees in the companies in doing its duties by following the performance of companies regularly and to identify the problems and obstacles facing the sector and the development of solutions and effective programs to prevent companies from exiting the market as result of financial failure .
\end{abstract}

Keywords: Audit Committees, Industrial Companies, Financial Failure.

\section{Introduction:}

The establishment of a mechanism or a pioneering and intellectual method by which to analyze and predict the possibility of companies having financial failure before a sufficient period of time is important matter in order to take appropriate measures to correct the financial situation, And the models of predicting financial failure is considered one of the most important tools used in the early detection of stumbling especially as it was built based on a set of scientific and global mechanisms to avoid the stumbling of companies in such phenomena.

The users of the financial reports and especially the senior management of the companies, lenders and investors, whether current or prospective, rely mainly on the financial and non-financial data extracted from these reports in their decisions making. And their confidence in the validity of these data is to the fact that there is a neutral intermediary which has conducted an audit of these reports that is containing financial statements and stating it's opinion on it as a result of the examination of inputs and ensuring their validity and compliance with international standards and local laws.

And because of the neutrality that is supposed to be characterized by the Audit Committee, an opinion will be made and notes will be taken without any discretion and position and impartiality so that the decision-maker would have the full picture on which to take the appropriate decision, and if there is any doubt shown that threatens with the financial failure of this institution and therefore non-continuity ,then the Audit Committee will disclose it to the Governing Council to correct the situation, and here decisions taken by the Governing Council, which would avoid these financial failures and address the causes depending on the nature of this doubt and its significance, And for the fact that the interest of the owners is to maintain the strength of ,or increase the financial position, this which will make the Governing Council take decisions that would make the necessary adjustments and correct situations, whether it's the change of management or the development of appropriate plans and policies to avoid reaching the stage of financial failure and thus liquidate its work . 
For that, this study aimed to identify the impact of the characteristics of the audit committees (the size of the Audit Committee, the number of independent members and the number of meetings of the Audit Committee) on avoiding financial failure in Jordanian Industrial Public Shareholding Companies listed in ASE

\section{Problem of the Study:}

The phenomenon of financial failure threatens the sustainability of companies of various types and lead them gradually to liquidation, so this phenomenon was the subject of interest and study and was given the experimental field framework embodies the possibility of avoidance and impact or at least reduce the rate by finding indicators that contribute to the interpretation and reveal in advance the possibility of occurrence (Boudiaf, 2018).

And because of the nature of the financial failure, which can be predicted and avoided if it was being dealt with and responded to in a timely manner. The problem of the study was posed by asking the following main question: Is there a statistically significant effect at the level of $(\alpha \leq 0.05)$ of the characteristics of the Audit Committees (size of the Audit Committee, number of independent members and number of meetings of the Audit Committee)on avoiding financial failure in Jordanian Industrial Public Shareholding Companies Listed on the Amman Stock Exchange. )?

\section{Purpose of the Study:}

The study aimed to identify the impact of the characteristics of the audit committees on avoiding financial failure in Jordanian Industrial Public Shareholding Companies listed in ASE, and what are the most important means to avoid these companies from falling into such a phenomenon.

\section{Significance of the Study:}

1-Scientific Significance :The importance of the study is to know the effect of the characteristics of the audit committees on avoiding financial failure by industrial companies through addressing the imbalance either by changing the management or modifying policies and strategies so that the continuity of the company is maintained and financial failure is avoided.

2- Practical Significance: This study is gaining importance through the role played by the Audit Committees because of its legal importance in many decisions that have a financial impact in avoiding many failures at the local and international level.

Hypothesis of the Study: In accordance with the objectives of the study to answer the question of the study problem, the hypothesis of the study was formulated as follows:

\section{Main Hypothesis:}

H0:There was no statistically significant effect at the level of $(\alpha \leq 0.05)$ of the characteristics of the Audit Committees (size of the Audit Committee, number of independent members and number of meetings of the Audit Committee)? Listed on the Amman Stock Exchange.

\section{Theoretical Part of the Study:}

\subsection{The concept of financial failure:}

Drapeau (2010) defines financial failure as "the stage at which the company cannot meet its short-term obligations on maturity, and in the subsequent period the entity loses the ability to pay interest on loans, bonds and preferred rights distributions such as preferred shares, forcing them to liquidate.

Financial failure is also defined as "the inability of the entity to achieve an appropriate return that exceeds the cost of the capital and is liquidated in this case optionally or because of a legal proceeding that expires in favor of creditors and in which case it is compulsorily liquidated" (Matar, 2010).

The definition of Gibson (2009: 451) was not very different, describing it as "the inability to meet short-term obligations and preferred stock distributions."

It is also described as "a term for the expression of the process of economic or financial unity that has begun to be exposed to a financial stalemate or a tendency towards hardship or financial bankruptcy (Hayes et.al, 2010)

Financial failure is also known as voluntary cessation of work due to financial default, and in this case it is liquidated by choice or due to a lawsuit in favor of the creditors, in which case it is compulsory (Mattar, 2001: 20) The researcher agrees with (Kassem 2009: 64) that failure in companies has two concepts, one is economic and the other is financial. The first is to measure success or failure depending on the amount of return on the capital and the company considered failing when it is unable to achieve an appropriate return on invested capital And the expected risks. The second concept indicates that the company is unable to meet its due obligations on time (Kassem, 2009: 64). 


\subsection{Stages of financial failure:}

Financial failure is considered the product of several successive stages, as agreed by the most researchers, which was divided into five stages:

1- the stage of incubation and development (deterioration of performance): during this phase indicators shows, such as early warning of financial failure, including low demand for products and increased competition and lack of credit facilities and increasing burdens without working capital (Sabri, 2018).

2- Cash Deficit Phase: This stage occurs when the management notices a financial default, usually when the company faces the inability to meet its immediate cash needs. At this stage, the company's assets are larger than its liabilities. The problem is the difficulty in converting these assets into Cash liquidity to cover outstanding debts, (Shibani, 2017).

3- Stage of financial deterioration: At this stage the company is unable to obtain the necessary funds which are fundamental to cover the debts owed, this stage can be addressed but it takes a long period of time, most companies that pass this stage can be successfully addressed if the defect was discovered in a timely manner,( Karrar, 2014).

4- the stage of total failure: This stage is a critical point in the life of the company, the company cannot avoid recognition of failure as the end of all the attempts of the administration to obtain additional funding, andAt this stage, the total crises exceed the value of the company's assets and financial failure and bankruptcy becomes legal proceedings (Al_Hamdani, Al-Qattan, 2013).

5- The bankruptcy declaration stage: It occurs when the legal procedures are taken to protect the rights of the lenders. Thus, the bankruptcy of the company is announced, ie liquidation of the company. Which is the final stage and thus the company has reached the stage of financial failure as the bankruptcy is the inevitable result of the continued liquidity deficit and the continuing financial insolvency facing the company and thus liquidate for the purpose of providing cash and payment of creditors (Al-Marshadi, 2018).

\subsection{The importance of predicting financial failure:}

The importance of financial failure comes from the concerns of interested parties in companies as follows:

- Banks: Banks are interested in predicting financial failure because of the impact on their existing loans and under study (Salah and Ghazwan, 2000: 178)

- Investors: Investors are interested in predicting financial failure for many reasons, including rationalizing its decisions, trade-offs between available alternatives, and avoiding risky investments (Sherif, 2006: 33).

- Management: The management is paying attention on the subject of financial failure to know the indicators of failure and its causes and procedures to address it before it occurs.

- Government agencies: These parties are concerned with the issue of financial failure as it considered a regulatory function (such as the control of financial companies and tax authorities and others).

- External Auditors: Their interest in this subject is reflected in the fact that they are responsible for evaluating the continuity of companies from their knowledge.

The manifestations of financial failure: There are two aspects of financial failure: (Said, 2000: 363). The economic appearance of the company's failure to achieve an appropriate return on the funds invested in it, and this applies to the company to achieve a return on investment less than the return cost of funds invested

. A financial appearance is the company's arrival to the point of the financial era or beyond to legal liquidation, and the company is legally insolvent when the carrying value of its products becomes less than the carrying amount of its obligations but reaches liquidation or financial bankruptcy when it fails to repay Debts.

\subsection{Financial Failure Prediction Models:}

In recent years, in the wake of the collapse of many international enterprises and companies, users of financial statements have given greater attention to finding ways and means to predict the company's status. The departments have also paid more attention to working on developing procedures and analyzes to test companies financially and forecast their future status to give early warning to correct situations in the case of any imbalance, and one of these methods is financial failure models that have increased interest and here several models will be addressed, including:

Altman Model: a model was adopted in 1968 and was developed in 1995 and during this model five ratios were selected and considered to be the characteristic of performance and this model has been used on a large scale to predict the bankruptcy of companies, through this model A linear relation was used between a set of variables that are best in distinguishing between failed companies and non-failed companies. The model in its mathematical form is as follows:

\section{$\mathrm{z}=1.2 \times 1+1.4 \times 2.3 .3 \times 3+0.6 \times 4+1.0 \times 5$}

$\mathrm{X} 1=$ Net working capital / total assets.

$\mathrm{X} 2=$ Retained earnings and reserves / total assets. 
$\mathrm{X} 3=\mathrm{EBITDA} /$ total assets.

$\mathrm{X} 4$ = Market value of equity / total liabilities.

$\mathrm{X} 5=$ Sales $/$ Total Assets. .

When the value of $(Z)$ is less than 1.81 , the probability of failure is large.

When $(Z)$ value is greater than 2.99 , it is highly unlikely to fail.

When the value of $(\mathrm{Z})$ between 1.81 (and 2.99), it is difficult to judge the possibility of success and failure of the company and called the gray area (Hamza, 2011: 307).

Sherarad Model: This model is used to assess the safety risk when granting bank loans and is also used to predict business continuity and depends on six financial ratios in:

$\mathrm{X} 1=$ Net Working Capital / Total Assets (Liquidity Index)

$\mathrm{X} 2$ = Current Assets / Total Assets (Liquidity Index)

$\mathrm{X} 3=$ Total shareholders' equity / total assets (leverage index)

X4 = Net Profit before Tax / Total Assets (Profitability Index)

$\mathrm{X} 5=$ Total assets $/$ Total fixed assets (leverage index).

$\mathrm{X} 6=$ Total shareholders' equity / total fixed assets (leverage index).

This model is in its mathematical form:

$=17 \times 1+92+3.53+20 \times 4+1.2 * 5+0.10 \times 6 z$

The risk index has been divided into the following categories (Mustapha 2008):

First: $\mathrm{Z}$ greater than or equal to 25 The Company is not liable to bankruptcy.

Second: $Z$ greater than or equal to 20 and less than 25 the probability of a low risk of bankruptcy

Third: $Z$ greater or equal to 5 and less than 20 difficult to predict the risk of bankruptcy

Fourth: $\mathrm{Z}$ greater than or equal to (-5) and smaller than 5 the company is exposed to bankruptcy risk

Fifth: $\mathrm{Z}$ less than (-5) the company is highly exposed to the risk of bankruptcy

The BEAVER model: This model relies on one financial ratio as a means of measuring the financial failure of an enterprise. The ratio varies from industry to another and is related to the entity's ability to meet its obligations (Peter, 1985: 529)

The concept of audit committees and their relation in reducing financial failure:

The audit committees are considered modern concepts of interest to many countries such as the United States of America, Canada, the United Kingdom, Australia and other countries. Many professional organizations have recommended the establishment of corporate audit committees for what they can do. Because it can play an important role in monitoring the financial reporting and disclosure to limit the financial failure, which led some countries to issue legislation binding for their presence in the companies participating in them.

\subsection{Audit committees in Jordanian laws and regulations:}

-Article (15) of the Companies' Disclosure Regulations, Accounting Standards and Auditing Standards of 2004 was issued. Where the following statement was made (JSC, 2016):

The board of directors of the issuing company shall form an audit committee consisting of three members of its nonexecutive natural members, one of whom shall be appointed chairman of the committee and inform the board, and any changes obtained and reasons thereof.

- All members of the committee must have knowledge in financial and accounting matters and at least one of them should have previous work experience in accounting, finance or other related fields.

- Member of the Board of Directors is not executive if he is not an employee of the company or receives a salary from them.

The Audit Committee meets periodically and submits its reports to the Board of Directors, provided that the number of its meetings is not less than four times a year and that the meetings should be written and recorded in a fundamental manner.

\subsection{The Audit Committee shall undertake the following tasks:}

1-Discussing the matters related to the candidacy of the external auditor and ensuring compliance with the requirements of the Authority and the absence of any impact on his independence and the impact of any other acts he performs for the company's account on this independence.

2-Examine all matters relating to the work of the auditor, including his observations, proposals and reservations, and follow up the response of the company management and make recommendations thereon to the Board of Directors. 
3-Review the correspondence of the company with the external auditor and evaluate the continent as well as make observations and recommendations thereon.

4-Follow up the company's compliance with the Securities Law and the regulations, instructions and decisions issued there under.

5-To review the periodic reports before submitting them to the Board of Directors and recommending them, with a focus on any changes in the accounting policies used and any change in the company's accounts due to the audits or as a result of the auditor's proposals.

6-Studying the auditor's work plan and ensuring that the company provides the auditor with all necessary facilities to carry out his work.

7-Examine and evaluate internal control procedures, review the external auditor's assessment of these procedures, and review the internal control reports, particularly those relating to any irregularities that arise as a result of the internal auditor's work.

8-Recommendation to the Board of Directors regarding matters related to the internal audit procedures and the work of the internal auditor.

9-Ensure that there is no conflict of interest that may result from the company making contracts, or entering into projects with related parties

10-Any other matters decided by the Board of Directors.

Chapter 1 from the fifth section of the Code of Corporate Governance for Listed Companies on the Amman Stock Exchange also discussed the Audit Committee. The JSC instructions referred to the following (JSC, 2009):

1- All members of the committee must have knowledge in financial and accounting matters. At least one of them must have previous work experience in accounting or financial matters and be a holder of a scientific qualification or a professional certificate in accounting, finance or other related fields.

2-The Committee shall meet periodically, and it should have at least four annual meetings.

3- The company shall put all the necessary resources at the hands of the committee to enable it to perform its work, including the use of experts

4- The Audit Committee shall meet with the Company's External Auditor without the presence of any person or representative of the Executive Management, at least once a year.

In the opinion of the researcher that these instructions came to provide transparency in the work of a committee to control the operation of the company, for the fear of the occurrence of actions that may lead to the collapse and failure at the local and global level

\subsection{The pillars of the audit committees and their relation in reducing the financial failure of companies:}

By considering the relevant Jordanian laws and regulations related to the audit committees and the relevant previous literature, it is concluded that the following principles or pillars must be available in the audit committees:

1- Independence of the Audit Committee: Independence requires from the Audit Committee to include non-executive board members, thus preventing the Executive Officer, the CFO and any other member of the Board of Directors of the Company from serving as a member of the Audit Committee.

The study (Klein, 2002: 39) suggests that the independence of audit committees reduces the likelihood of management manipulating profits. The study(Carcello et al. , 2000, 457) Shows that there is a positive relation between audit committees and audit fees, which indicates that the independence of the Audit Committee leads to better quality of financial report to avoid failure and corporate collapse. In addition, a study (Ali et al., 2009: 627) found that companies with independent audit committees have better institutional governance.

2- Meetings of the Audit Committee: Regulations and laws stipulated that there should be meetings of the Audit Committee to discuss certain issues and issues related to the conduct of operations. The committee must meet periodically, with at least four meetings annually.

Ismail et al. (2008: 187) believes that the meetings of the Audit Committee are an important tool for verifying that the members of the committees fulfill the tasks assigned to them by the Company. (Bedard et al. 2004: 27) believes that the audit committees should carry out their functions efficiently by increasing the frequency of meetings in order to maintain the function of supervision over the company's business and quality to avoid any risks that may result in failure.

3- The financial expertise of the Audit Committee: The complexity of existing financial instruments and the complexity of corporate capital structures as well as the emergence of new industries and the orientation towards international 
accounting standards and all financial reporting standards, together illustrate the importance of having qualified members of the Audit Committee and having sufficient practical experience.

(DeZoort et al., 2003 (180)) points out that the experience of the members of the audit committees is important to help them deal with the external auditors, adding that the members of the audit committees, especially the professional certificate holders, understand the responsibilities and duties of the auditor more than their counterparts.

\subsection{Preventive measures to reduce company's failure:}

(Mbat \& Eyo .2013) believes that the lessons learned from failed companies' experience should be taken into account and the reasons for failure of these companies should be studied. The effective institutions must use the procedures and actions that have proven effective and have been tested and proved successful on the ground to avoid the phenomenon of companies failure, and those actions are summarized as follows:

- To consider all areas of operations in order to evaluate its efficiency, including the following areas: training and development of staff, and in order to raise the level of efficiency and productivity, it is important to work to assess the work of each employee compared to what is expected of them

- Strengthen operations and production capacity and apply the appropriate financial structure, increasing the competitive level to become an advantage in the market.

- Effective management of product marketing

Good management must recognize that controlling and monitoring important factors, such as the price of products and goods, the quantity of sales, the size of the market and the market share, ensure that it succeeds in achieving its objectives and goals.

\section{Previous studies}

A study (Abu Shehab, 2018) entitled "Effectiveness of the KIDA model to predict financial failure in the shareholding companies in Amman Stock Exchange"

This study aimed to answer the following question: Is there an effectiveness of the KIDA Model to predict the financial failure of the shareholding companies in Amman Stock Exchange? This model has been applied to 10 companies that have been referred for liquidation or suspended companies and 10 ongoing companies (not for liquidation), The study found a number of results as follows: It was noted that the number of companies that have achieved KIDA Model in terms of predicting financial failure and referral to liquidation has reached 8 out of 10 companies that were included in the sample of the study and were referred for liquidation, While the results of the KIDA Model were not achieved by two companies referred to the liquidation, ie $80 \%$ of the sample, while the number of companies that achieved Kida model in terms of showing the lack of determinants of financial failure and non-referral liquidation was 3 out of 10 companies that were Included in the study sample and were referred for liquidation, the results of the KIDA model did not materialize in was 7 out of 10 companies that showed financial failure. They were out of 20 companies which were not assigned for liquidation. It was noted that the total number of companies that achieved the model was 11 companies out of 20 companies referred and not referred for liquidation which as a percentage of 55\% that were included in the study sample, The total number of companies that did not achieve the model was 9 out of 20 companies that were not assigned for liquidation. In general, it was noted that the KEDA model was inclined to predict financial failure, which provides an indication that the model reflects any difficulties or financial changes that the company is experiencing as being threatened with financial failure and that it is reliable in judging the financial position of companies but with a low level of confidence.

(Al-Rifai, 2017) Study entitled: "Predicting companies' stumbling using the Altman model: A study on the industrial companies listed on the Amman Stock Exchange.

The objective of this study is to conclude the result of that if the Altman model has the ability to predict the financial stumbling before it happening at least two years before, test was conducted on the companies whose financial data are available during the study period from 2011 to 2015 , The sample consisted of 61 industrial companies listed on the ASE, and to achieve the objectives of the study, the researcher adopted the experimental method and descriptive analytical method through a test study based on actual data derived from the financial reports published in the ASE for the period 2011-2015.

In order to analyze the data of the study and test the main hypothesis, the researcher adopted Altman model (1968) to measure its ability to predict the failure of companies in the study sample of industrial companies over 5 years. The results showed that the Altman model has the ability to predict the failure of companies within two years before stumbling In the industrial companies listed on the ASE. It also showed a statistically significant effect of the contents 
of the Altman model of $(\mathrm{X} 1, \mathrm{X} 2, \mathrm{X} 3$ and $\mathrm{X} 4)$ combined and separately on the actual EPS performance of industrial companies listed on the Amman Stock Exchange.

The study recommended that investors, financial analysts and auditors should be encouraged to use the Altman model to study the financial situation of the company and make appropriate investment decisions in it.

(Al-Ammar and Al-Qasiri 2015) study entitled "Comparative Study of Financial Failure Predictability Models" The objective of this study, using the models of predicting financial failure, is to identify the future probability of financial failure of the studied company, And that these models are based primarily on a set of financial ratios that collectively constitute an indicator that can be used to assess potential future financial stumble. The problem of the study lies in the absence of an approved model for predicting financial failure in Syria, in spite of the abundance of available models. The aim of the research is to introduce the concept of financial failure and its importance and to present a summary of the most important models of predicting financial failure and then to compare them, The models are accurate in predicting financial failure to suit the Syrian banking and financial environment.

The researchers found a number of results, the most important of which is that despite the importance of the criterion of multiple ratios and their diversity, and the criterion of accuracy of prediction in the first year of the probability of failure, the criterion of sample size in which the model is tested remains the most important, (Shirata, 2002) with the large size of the test sample. The recommendations of the research were to adopt the( Shirata2002) model to predict financial failure as it is more suitable for the Syrian environment if no local models are available, stressing the need to find a special model for predicting and testing financial failure on a sample of Syrian companies, And to use in the preparation of this model (Altman1968) model because it is the starting point for many previous models and (Shirata2002) because it is one of the latest models, in addition to the Altman model.

(KEENER M . H)2013,study entitled "Predicting the financial Failure of Retail companies in the united states"

This study aimed to test the application of financial failure predicting models to the retail sector in the United States. The researcher used the method of logistic analysis to predict financial failure. The sample included companies that publicly practice retailing in the United States during the period 2005-2012, The researcher concluded an expected results that provide clear evidence of the possibility of using quantitative models to predict financial failure, The results showed that the most likely companies for financial failure were those characterized by low cash rates, low cash flow margins and high debt equity ratio.

\section{(Mazouz, et al , 2012 ) study entitled " The impact of cash flow on business failure"}

The study aimed at determining the effect of cash flow indicators on the use of the failure predicating model. The sample included 10 banks, 5 of which failed during the study results. And found that the results of financial failure models in banks investigated acceptable for application by $92 \%$ and rejected by $77 \%$. The results of the cash flow indicators are acceptable to apply at $94 \%$ and are rejected by $82 \%$. The recommendation was to develop the banks' capabilities based on the cash flow indicators within the financial failure models, The idea of the research is based on the results of most previous studies, with a difference in models of measurement of financial failure and the approved sample as it aims to highlight the importance of KIDA model to predict financial failure and its compatibility with operational cash flow indicators. Which expressed accurately the quality of profits and efficient performance in the exploitation of available resources to achieve the possibility of continuity of business for future periods in the studied banks.

\section{Practical Side of the Study:}

Methodology: The study was based on the analytical descriptive approach which is based on the use of different statistical methods to analyze the data gathered from the field of the study sample in order to describe the variables of the study and answer its questions and test its hypotheses.

\subsection{Study sample}

The sample of the study consisted of the industrial joint stock companies listed on the Amman Stock Exchange which reached (67) by the end of 2017, distributed over 10 industrial sectors, according to the companies directory from the official website of the ASE. The sample of the study included (49) companies, which applied the conditions of selection of the sample, which were as follows:

1. The company is traded in the financial market during the study period.

2. The company shall not be subject to compulsory or voluntary liquidation.

3. The company has all the necessary data to calculate the variables of the study that is needed for the variables of the study model.

4. The company's financial year ends on 31-12 of each year. 


\subsection{Data collecting methods}

The study relied in data collection on the following sources:

1- Secondary data: The books, periodicals, university letters and publications related to the subject of the study.

2- Preliminary data: These are the annual reports and disclosures published by the companies to collect data on the characteristics of the audit committees and the annual financial statements published during the period 2014-2017 to collect data on the financial ratios of the application of the Altman model to measure financial stumbling.

\subsection{Statistical methods used}

Using the SPSS program to analyze the study data, the following statistical tools were used as well:

1. Descriptive statistics, which included arithmetical averages, standard deviations, duplicates, and percentages, to describe the variables of the study.

2- Multiple linear correlation test using Pearson correlation coefficient, and self-correlation test using correlation coefficient (Durbin-Watson)).

3 - Multiple Linear Regression Analysis, to test the effect of independent variables on the dependent variable

\subsection{Description of study variables}

The researcher relied on descriptive statistics to describe the variables of the independent and dependent study, which were collected from the reports, financial statements and disclosures published by the Jordanian industrial companies, during the period 2014-2017. The results were as follows:

Table (1): Descriptive Statistics of the Audit Committee Characteristics during the Period (2014-2017)

\begin{tabular}{|l|l|l|l|l|}
\hline Variable & $\begin{array}{l}\text { The size of the } \\
\text { Audit } \\
\text { Committee } \\
\text { (member) }\end{array}$ & $\begin{array}{l}\text { Number } \\
\text { Independent } \\
\text { Members } \\
\text { (Member) }\end{array}$ & $\begin{array}{l}\text { Percentage of } \\
\text { Independent } \\
\text { Members (\%) }\end{array}$ & $\begin{array}{l}\text { Number of Audit } \\
\text { Committee } \\
\text { Meeting(number) }\end{array}$ \\
\hline Mean & 3.1 & 0.3 & 9.3 & 3.7 \\
\hline $\begin{array}{l}\text { Standard } \\
\text { deviation }\end{array}$ & $\mathbf{0 . 4}$ & $\mathbf{0 . 9}$ & 27.4 & 1.1 \\
\hline Highest value & $\mathbf{5 . 0}$ & 4.0 & 100.0 & $\mathbf{6 . 0}$ \\
\hline Lowest value & 2.0 & 0.0 & 0.0 & 1.0 \\
\hline
\end{tabular}

Table 1 presents a description of the characteristics of the audit committees of the Jordanian industrial companies during the period 2014-2017, represented by the size of the Audit Committee, the number of independent members and the number of meetings of the Audit Committee. The table above shows the following:

1. The arithmetical average of the size of the Audit Committee of the Jordanian industrial companies during the period 2014-2017 was 3.1 members, with a standard deviation of 0.4 members. The Highest value was (5.0), while the lowest value (2.0) Member. From previous measurements, there is a relative convergence between the industrial companies in terms of the number of members of the audit committees.

2. The average number of independent members of the Audit Committee of Jordanian Industrial Companies during the period 2014-2017 was( 0.3) members, with a mean percentage of 9.3\%, and the deviation was (0.9). The highest value was (4.0) members, with the percentage of $100.0 \%$ of the members of the Audit Committee. While the lowest value was $(0.0)$ members, which accounted for $(0.0 \%)$ of the number of members of the Audit Committee. From the previous measurements, there is a discrepancy between the Jordanian industrial companies in terms of the number of independent members of the audit committees. This may indicate that industrial companies use external parties to form audit committees.

3. The average number of meetings of the Audit Committee of the Jordanian industrial companies during the period 2014-2017 reached(3.7) meetings, with a standard deviation of (1.1) meetings. The highest value reached (6.0) meetings, while the lowest value (1.0), The previous measurements show a discrepancy between the Jordanian industrial companies in terms of the number of meetings of the audit committees during the year, which may be due to the size of the company and the nature of the activities and tasks carried out by it . 
Table (2): descriptive statistics to avoid financial failure in industrial companies for the period (2014-2017)

\begin{tabular}{|l|l|l|l|}
\hline Variable & Category & Number of views & Percentage \% \\
\hline \multirow{4}{*}{ Avoiding financial failure } & Not threatened by financial failure & 140 & 71.4 \\
\cline { 2 - 4 } & threatened by financial failure & 56 & 28.6 \\
\cline { 2 - 4 } & Total & 196 & 100
\end{tabular}

Table (2) presents a description of the financial stumbling in Jordanian industrial companies during the period 20142017. It is clear from the table above that the proportion of industrial companies not threatened by financial failure according to Altman model reached (71.4\%), while the proportion of companies threatened with financial failure reached (28.6\%), this indicates the ability of the majority of industrial companies to avoid financial failure.

\subsection{Test of the study hypotheses}

The study depended in testing the hypothesis on multiple regression analysis in order to answer the study questions. Before the analysis was carried out, it was confirmed that the data is free from the multiple correlation phenomenon. This phenomenon indicates that there is an almost linear correlation between two or more variables that works on making the value of coefficient of determination R2 greater than its actual value. Therefore, the linear correlation coefficient and the variance inflation factor value of each variable tested have been calculated. The results were as follows:

Table (3): The correlation matrix for independent variables

\begin{tabular}{|l|l|l|l|}
\hline Variable & $\begin{array}{l}\text { The size of the Audit } \\
\text { Committee }\end{array}$ & $\begin{array}{l}\text { Number of Independent } \\
\text { Members }\end{array}$ & $\begin{array}{l}\text { Number of Audit } \\
\text { Committee Meeting }\end{array}$ \\
\hline $\begin{array}{l}\text { The size of the Audit } \\
\text { Committee }\end{array}$ & 1.000 & & \\
\hline $\begin{array}{l}\text { Number of Independent } \\
\text { Members }\end{array}$ & $0.284 * *$ & 1.000 & 1.000 \\
\hline $\begin{array}{l}\text { Number of Audit } \\
\text { Committee Meeting }\end{array}$ & 0.079 & 0.014 & \\
\hline
\end{tabular}

**significant the level of significance 0.01

Table (3) shows that the highest value of the correlation coefficient was found between the independent variables (the size of the audit committee) and the number of independent members reached (0.284), while the correlation coefficient between the other independent variables was less than that, This indicates that there is no multi-linear correlation between independent study variables, The linear correlation coefficient values that exceeds $(0.80)$ may be considered an indicator of multiple linear correlations (Guajarati, 2004, 359). Therefore, it is possible to say that the study sample is free of the high multi linear correlation problem

It was also confirmed that the data was free of the self-correlation problem, known as the association between random error limits in the regression model, resulting in a bias in the estimated parameters, Thus the weakening of the model's ability to predict. This is confirmed by the (Durbin-Watson test), which is the most common and used, the value of this test is between the two numbers $(0$ and 4$)$. The existence of the self-association phenomenon is rejected if the value of $\mathrm{D}-\mathrm{W}$ is equal to or close to 2 (Gujarati, 2003, 496).

The results of the Durbin-Watson test showed that the value of D-W was (1.902), which is approaching the number 2, indicating the absence of data from the auto-correlation problem, ie, there was no correlation between random error limits in the regression model.

Test results of the main hypothesis H0: There is no significant statistical effect at the level of significance $(\alpha \leq 0.05)$ of the characteristics of the Audit Committees (size of the Audit Committee, number of independent members and number of meetings of the Audit Committee on avoiding financial failure in Jordanian Industrial Public Shareholding Companies Listed on the Amman Stock Exchange

To test this hypothesis, multiple linear regression analysis was used, and the results are as shown in Table (4) 
Table ( 4 ) Test results of the main hypothesis H0:

\begin{tabular}{|c|c|c|c|c|c|}
\hline \multirow[b]{2}{*}{ Dependent variable } & \multirow[b]{2}{*}{ Independent Variable } & \multicolumn{4}{|c|}{ Table of Coefficients } \\
\hline & & B & $\begin{array}{l}\text { Standard } \\
\text { Error }\end{array}$ & $\begin{array}{l}\text { T } \\
\text { Calculated }\end{array}$ & Sig $t^{*}$ \\
\hline \multirow{3}{*}{ Avoiding financial failure } & The size of the Audit Committee & 0.219 & 0.107 & 2.048 & 0.042 \\
\hline & Number of Independent Members & 0.048 & 0.032 & 1.484 & $\mathbf{0 . 1 3 9}$ \\
\hline & Number of Audit Committee Meeting & 0.067 & $\mathbf{0 . 0 2 8}$ & 2.343 & $\mathbf{0 . 0 2 0}$ \\
\hline \multicolumn{2}{|l|}{ Correlation coefficient $\mathbf{R}$} & \multicolumn{4}{|l|}{0.258} \\
\hline \multicolumn{2}{|c|}{ Coefficient of determination $\mathrm{R}^{2}$} & \multicolumn{4}{|l|}{0.067} \\
\hline \multicolumn{2}{|l|}{ Calculated $F$ value } & \multicolumn{4}{|l|}{4.273} \\
\hline \multicolumn{2}{|l|}{ Sig. F* } & \multicolumn{4}{|l|}{0.004} \\
\hline
\end{tabular}

\section{$* *$ The effect is statistically significant at level $(\alpha \leq 0.05)$}

The results of Table (4) indicate that the correlation coefficient $(\mathrm{R}=0.288)$ refers to the relationship between independent and dependent variables. The effect of the independent variables (the characteristics of the audit committees) on the dependent variable (avoiding financial failure)Is a significant positive effect of statistical significance, Where the value of the calculated F is 4.273 and the level of significance $(\mathrm{Sig}=0.004)$ is less than 0.05 . The value of the coefficient of determination $(\mathrm{R} 2=0.067)$ indicates that $(6.7 \%)$ of the variance in (avoidance of financial failure) can be explained through the variance in (the characteristics of the audit committees) combined.

The table of coefficients showed that the value of B at (the size of the Audit Committee) reached (0.219) and the value of $\mathrm{t}$ is (2.048) and the level of significance ( $\mathrm{Sig}=0.042)$, indicating that the effect of this dimension is significant. The value of $B$ at (the number of independent members) reached 0.048 and the value of $t$ is $(1,484)$, and at a significance level ( $\mathrm{Sig}=0.139)$ Indicating that the impact of this dimension is insignificant. The value of $\mathrm{B}$ at (number of meetings of the Audit Committee) is (0.067), the value of $\mathrm{t}$ is (2.343), and the significance level ( $\mathrm{Sig}=0.020)$, indicating that the effect of this dimension is significant.

Based on the above, we reject the basic null hypothesis and accept the alternative hypothesis that states:

There is significant statistical effect at the level of significance $(\alpha \leq 0.05)$ of the characteristics of the Audit Committees (size of the Audit Committee, number of independent members and number of meetings of the Audit Committee on avoiding financial failure in Jordanian Industrial Public Shareholding Companies Listed on the Amman Stock Exchange

\section{Results:}

1. There is a relative convergence between the industrial companies in terms of the number of members of the audit committees.

2. There is a difference between the Jordanian industrial companies in terms of the number of independent members of the audit committees, which may indicate that industrial companies use external parties to form audit committees. 3. There is a difference between the Jordanian industrial companies in terms of the number of meetings of audit committees during the year, and this may be due to the difference in size of the company and the nature of the activities and tasks carried out by it

4. The proportion of industrial companies not threatened by financial failure according to the Altman model reached (71.4\%), while the percentage of companies threatened with financial failure reached (28.6\%). This indicates the ability of most industrial companies to avoid financial failure.

5. There is significant statistical effect at the level of significance $(\alpha \leq 0.05)$ of the characteristics of the Audit Committees (size of the Audit Committee, number of independent members and number of meetings of the Audit Committee on avoiding financial failure in Jordanian Industrial Public Shareholding Companies Listed on the Amman Stock Exchange

\section{Recommendations:}

Based on the findings of the study, it recommends the following:

1. The need to raise the awareness of the managers and employees of the companies involved in the industrial sector with the unethical view of some of their practices in order to reduce the company's exposure to financial failure and thus its non-continuity and survival in the market.

2. Supervising entities through the audit committees in companies to fulfill their duties by following the performance of companies on a timely basis and to identify the problems and obstacles facing the sector and to develop solutions and 
effective programs in order to prevent companies from leaving the market due to their financial failure. 3. The need to proceed with research on the factors and effects that limit the financial failure of industrial companies as a proactive attempt to predict financial failure before it occurs

4. The Following of the management of industrial companies to a various financing methods and policies in the financing of its assets, and focusing on self-financing rather than focusing on external debt.

5.Emphasizing on the importance of Association of Certified Public Accountants in preparing courses aimed at employees in the companies to know the risks of financial failure surrounding their companies and ways to confront it.

\section{References}

Abu-Shehab, Ezzat Hani, (2018). Effectiveness of the Kida model on forecasting financial failure in joint stock companies in Amman Stock Exchange Unpublished Master Thesis, Middle East University, and Amman, Jordan.

Ali Shah, S.Z., Ali Butt S. and Hasan, A., Corporate governance and earnings management an empirical evidence form Pakistani listed companies. European Journal of Scientific Research, Vol. 26, No. 4, P: 624-638,) 2009(.

Al-Ammar, Radwan, and Qusairi, Hassan, (2015), "Comparative Study of Financial Failure Predictability Models," Tishreen University Journal for Research and Scientific Studies, Volume 37, No. 5, pp. 127-145.

Al-Hamdani, Rafi'a Ibrahim, Al-Qattan and Yassin Taha Yassin, (2013)"The Use of the Sherrod Model for Predicting Financial Failure: An Empirical Study in the General Company for the Manufacture of Medicines and Medical Devices in Nineveh", Anbar University Journal of Economic and Administrative Sciences, Vol. 5, No. 10, p. 449- Jordan Securities Commission / Corporate Governance Rules Guide (2009)

Al-Morshedi, Abbas Alwan Sharif, 2018, "Using the Sherrod Model to Predict the Financial Failure of Private Commercial Banks in Iraq: An Applied Study in a Sample of Banks Listed in the Iraqi Stock Exchange", Journal of Babylon University for Banking and Applied Sciences, Volume 16, , No. (1), pp. 253-275.

Al-Rifa'i, Hashim Ahmad, (2017), "Predicting Companies' stumbling Using the Altman Model: A Study on Industrial Companies Listed on the ASE Market, Unpublished Master Thesis, Middle East University, Amman, Jordan

Bedard, J., Chtourou, S.M. and Courteau, L., The effect of audit committee expertise, independence, and activity on aggressive earnings management. Journal of Auditing,Vol. 23, No.2, P: 23-36.(2004) . [12] Bursa Malysia website, Retrieved 12 July 2010 at http://www.bursamalysia.com.

Boudiaf, Safa, (2018), "The Role of Financial Performance Assessment Indicators in Predicting Financial Failure - An Empirical Study on a Sample of Milk Sector and Milk Products", Journal of Economic Research, Blida University, 2, Algeria, p 294-312

Carcello, J.V. and Neal, T.L., Audit Committee Composition and Auditor Reporting. The Accounting Review. Vol. 75, No. 4, P: 453-467,(2000).

DeZoort, F.T., Hermanson, D. R. and Houston, R. W., Audit committee support for auditors: the effect of materiality justification and accounting precision. Journal of Accounting and Public Policy. Vol. 22, P:175-199(2003).

Drapeau,Retchard,(2010),"Bankruptcy prediction Model using discreminant analyses on financial ratio derived from corporate balance sheets",Multinational Finance Journal.Vol 3.(2):71-101.

Gibson,C,H,(2009),"Financial Reporting \&Analyses",11,Edition,USA-Ohaio.

Green، W. H. (2003). Econometric Analysis، fifth ed، Prentice Hall، USR NJ 07458

Hayes, Suzanne K. \& Hodge, Kay A. \& Hughes, Larry W. , (2010), " A Study of the Efficacy of Altman's Z To Predict Bankruptcy of Specialty Retail Firms Doing Business in Contemporary Times", Economics \& Business Journal: Inquiries \& Perspectives, vol.3, no.1,pp 123-134

Ismail, H., Mohd. Iskandar, T., and Mohid Rahmat, M. , Corporate reporting quality, audit committee and quality of audit, Malaysian Accounting Review, Vol 7, No 1,P: 21-42,(2008).

Karrar, Abdul al'ilah Aziz, (2014),"The Role of Forecasting Financial Failure and Operational Cash Flow Indicators in Banking Stabilization using the Kida Model", Al-Ghari Journal of Economic and Administrative Sciences, University of Kufa, Volume 7, Issue 30, 250-325 .

Keener, M.H. (2013) Predicting The Financial Failure of Rtail Companies in The United States, Journal of Business \& Economics Research, Vol. 11. No. 8, p 373-380

Klein, A., Economic determinants of audit committee independence,. Accounting Review,Vol. 77, No.2, P: 35-52 ,(2002).

Matar Hammad Hamdi Ismail (2010), "Proposed Model for Forecasting Impairment of Public Banking Facilities in Palestine", Master of Accounting and Finance, Islamic University, Gaza, Palestine, p 52

Matar Mohammed, The Nature and Importance of Financial Failure Indicators for Companies, Al-Yaseer Magazine, Petra University Jordan, 2001, p20 
Mazouz, A., \&Crane, P., (2012) The Impact of cash flow on business failure analysis \&prediction, International journal of business \& financial, Vol.402, U.S.A

Mbat, D., \& Eyo, E. (2013). Corporate Failure: Causes and Remedies. Business and Management Research, Vol. 2, No. (4). http://dx.doi.org/ 10.5430/bmr.v2n4p19

Peter, C., (1985), Financial Distress: Comparative Study of Individual Model And Committee Assesment, Journal of Accoounting Research, Vol. 23.

Qasem Al-Habet, Using Financial Analysis Models for the Test of Corporate Continuity, Rafidain Development Journal, Issue 64, 2009, p. 11

Sabri, Thamer Mahdi Mohamed, (2018), "The Importance of Using Predictability Models for Financial Failure in Evaluating Companies Continuity or Financial failure ", Journal of the Faculty of Management and Economics for Economic, Administrative and Financial Studies, No. 3, Vol. 10, p 386

Said Abdel Salam, The Italian Arab bank, Publishing House, Italy, 2000, p. 363

Saleh, Essam Mohammed and Sulaim, Ghazwan and Munir, Mustafa, 2000, "Analysis of Institution Building is a Function to Predict Financial Failure: An Empirical Study on a Sample of Iraqi and Jordanian Contribution Companies," Journal of Al-Rafidain College, University of Science, 3rd Year,p 178

Securities Commission (2016). Directory of Corporate Governance Rules for Public Shareholding listed on the Amman Stock Exchange. www.jsc.gov.jo/.

Sharif, Rihani, (2006), published research, efficiency and effectiveness of quantitative models to predict the technical bankruptcy of the economic institution."Journal of Gendol, Journal of Human Sciences", fourth year, issue 30.

Shibani, Sarah, (2017), "The role of accountant in forecasting the financial failure of economic institutions - An exploratory study of a sample of external auditors", unpublished master thesis, Al-Arabi Bin Al-Muhaidi University, Um Al-Bouaqi, and Algeria.

http://www.jsc.gov.jo473. 